\title{
Safety and efficacy of different insulin regimens in treatment of type 2 diabetes patients who insist on fasting during ramadan 1437 (Hijri) In Fayoum Governorate, Egypt
}

Mohamed A Mashahit ${ }^{(1)}$, Riham Ahmed Abd El Aal ${ }^{(2)}$, Othman Zaki ${ }^{(3)}$ and Eman M Ezzat $^{(1)}$

${ }^{(1)}$ Department of Internal medicine, Fayoum University, Egypt

${ }^{(2)}$ MBBCh, Fayoum University, Egypt

${ }^{(3)}$ Department of Clinical \& Chemical pathology, Fayoum University, Egypt

Corresponding author: DR,Eman Mahmoud Ezzat

E-mail address: eme11@fayoum.edu.eg

Fax: +2084636583

\begin{abstract}
:
Background: Fasting during Ramadan is an obligatory ritual for every healthy adult Muslim. However, a lot of type 2 diabetic Muslim patients insist on fasting whatever their health status. There are several potential physiological benefits from fasting, but the prolonged fasting hours during summer provides many questions about safety and efficacy of different insulin regimens used for the treatment of type 2 diabetic patients during Ramadan fasting.
\end{abstract}

Objective: to assess safety and efficacy of different insulin regimens in type 2 diabetic patients who insist on Ramadan fasting.

Patients and methods: This study was conducted on 337 type 2 diabetic patients who were divided into 3 groups (I, II, and III) receiving different regimens of insulin therapy (oral, premixed, and basal-bolus regimens respectively) alone or combined with oral antidiabetic drugs. For all participants, the following procedures were done: structured educational sessions, history taking, clinical examination, and assessment of blood pressure, waist circumference, body mass index, blood glucose, glycated hemoglobin, liver and renal function tests, and lipid profile before and after Ramadan fasting. During Ramadan, all participants were asked to record readings for the fasting blood glucose at noon and $6 \mathrm{pm}$, as well as the postprandial readings 1-2 hours after breakfast on days 2 , 
14 , and 28. Also, to report any day that fasting was broken and the cause for this.

Results: Hypoglycemic events whether documented or symptomatic (44\% and 52\% respectively) were more prevalent among patients on the basal-bolus insulin regimen, with the number of episodes of documented hypoglycemia per patient significantly higher in this regimen (1.9 \pm 0.9$)$ compared to the other two regimens and this difference was statistically significant ( $\mathrm{P}=0.046)$.. A significant reduction in glycated hemoglobin was reported among patients using premixed insulin with or without oral antidiabetic medications ( $\mathrm{P}<0.0001)$, however, patients on this regimen had the highest prevalence of non-fasting days (44.6\%) due to DM.

Conclusion: The current study reported comparable results regarding safety and efficacy of the three studied insulin regimens used for treatment of type 2 diabetic patients during Ramadan fasting. No regimen proved to be superior. Patient education before Ramadan fast is a mandatory step in management.

Keywords: Type 2 Diabetes Mellitus; Ramadan; Fasting; Egypt; Insulin.

\section{Introduction:}

Ramadan fasting is an obligatory Islamic rite on each grown healthy Muslim. There is exemption for sick individuals from its fasting, nevertheless a lot of sick people insist on fasting. Type 2 diabetes mellitus (T2DM) is a great problem both worldwide and in Egypt. Recently, the number of diabetics in Egypt was estimated to be over 8.2 million patients, and it is expected to increase in the upcoming years. $\left[{ }^{1}\right]$

Fasting requires complete abstinence from food and drinks, and it may reach up to 16 hours in the summer months; hence, there might be a risk for adverse health events especially hypoglycemia in diabetic patients who fast Ramadan. $\left.{ }^{2}\right]$ Augmentation of this risk may occur in patients with T2DM who are receiving insulin therapy with or without oral antidiabetic drugs (OAD). $\left[{ }^{3}\right]$ In addition, those patients are more vulnerable to hyperglycemic events such as ketoacidosis. $\left[{ }^{2}\right]$

Patient education, self-monitoring of blood glucose (SMBG), and improving medical care during Ramadan fasting with individualization of management have been found effectively reducing complications in those patients. $\left.{ }^{4,5}\right]$ T2DM patients wellcontrolled on premixed insulin or multiple doses injections should not fast, and they 
have the legitimate exemption for this.

However, many Muslim patients insist on fasting in spite of medical warning. $\left[{ }^{2}\right]$ So, we aimed in the current study to assess Safety and Efficacy of different insulin regimens in type 2 diabetic patients who insist on Ramadan fasting.

\section{Patients and Methods:}

The current study was approved by our local Ethics Committee, and an informed written consent was obtained from each participant.

We conducted a prospective cohort study on 500 type 2 diabetic patients receiving insulin therapy, only 337 completed the study.

Participants were recruited from Diabetes and Internal Medicine outpatient clinics of Fayoum University Hospital, Egypt, from May to August 2016 [1437 Hijra].

We included all adult (18 to 65 years-old), Muslim, type-2 diabetic patients, insisting on Ramadan fasting, and receiving insulin therapy (basal, pre-mixed or basal-bolus regimen) alone or combined with oral antidiabetic drugs (metformin, sulfonylurea: gliclazide, dipeptidyl peptidase 4 Inhibitor: sitagliptin or vildagliptin or thiazolidinediones/glitazones). We excluded type 1 diabetics, uncontrolled type 2 diabetics $(\mathrm{HbA} 1 \mathrm{c}>9$; but they were included if insisting on fasting despite the detailed medical advice), high-risk and very high-risk diabetics (according to IDF/DAR 2016 classification) $\left[{ }^{6}\right]$, newly diagnosed as diabetics (<3 months), and patients with previous ketoacidosis or hyperosmolar hyperglycemic states, recurrent or severe hypoglycemia within the past 2 months, and those with hypoglycemic unawareness. Hospitalized patients, besides pregnant and lactating females were also excluded.

Based on their insulin treatment regimens, the study subjects were grouped as: group I (87 patients using basal insulin with or without OAD); group II (175 patients using premixed insulin regimen with or without OAD); and group III (75 patients using basal-bolus regimen with or without OAD). A full medical history was taken for all participants; including disease duration, type and dose of the current medications, as well as concomitant comorbidities. A thorough clinical examination was performed with measurements of blood pressure (using a standard sphygmomanometer with an appropriate size cuff), body weight (in kilograms), height (in centimeters), and waist circumference (in centimeters). We calculated the body mass index as 
weight/height2 $(\mathrm{kg} / \mathrm{m} 2)$. We assessed the following parameters pre and post Ramadan fasting: the fasting blood glucose (FBG), 2hours postprandial blood glucose( $2 \mathrm{hs}$ PPBG), glycated hemoglobin (HbA1c), liver and renal function tests (including liver enzymes AST and ALT, serum urea, creatinine, uric acid, and urinary albumin/creatinine ratio (UACR)), total cholesterol (TC), triglycerides (TG), low density (LDL-C) and high density cholesterol levels (HDL-C).

In addition, the following procedures were carried out:

\section{Before Ramadan (Visit A): Each}

patient had a structured educational session, a glucometer for self-blood glucose monitoring, and a diary for recording measurements and events 4 to 6 weeks before Ramadan. The doses of insulin and OADs were modified according to IDF/DAR 2016 guidelines. ${ }^{[6]}$ All patients were instructed clearly to break Ramadan fasting if the blood glucose was less than 70 , or more than $300 \mathrm{mg} / \mathrm{dl}$, or they had significant hypoglycemic symptoms; with recording of all the measurements and events.

\section{During Ramadan: All patients were} informed to regularly record their FBG at noon and $6 \mathrm{pm}$ and postprandial level 1-2 hours after breakfast on the second day of Ramadan, mid Ramadan and near the end of Ramadan), in addition to recording any day the fasting was broken and the cause for this.

\section{After Ramadan (Visit B): Re-}

assessment of the patients' anthropometric and laboratory measurements was performed 2 to 4 weeks after Ramadan.

Patients who developed any of the exclusion criteria at any stage of the study were excluded. The effect of Ramadan fasting on anthropometrics and laboratory measurements was analyzed and any hypo/hyperglycemic events, the number of fasts broken, and the need for an emergency room visit or hospitalization due to adverse glycemic events or any other cause during Ramadan fasting were documented.

\section{Statistical Analysis:}

Data analysis was performed using SPSS software version 18. All numerical variables were checked for normality by Shapiro Wilk test. Qualitative data were summarized as frequencies and percentages, and association between variables was tested using Chi 
square test. Quantitative parametric data

were expressed as arithmetic means and standard deviations, and association between variables was tested using one-way analysis of variance test. Pearson's test was used to test the correlation between variables. A pvalue of $<0.05$ was considered statistically significant.

\section{Results:}

Out of 500 type 2 diabetic patients recruited, only 337 completed the study, most of them (209, 62\%) were females. Group I included 87 patients using basal insulin with or without OADs, group II included 175 patients using premixed insulin regimen with or without OADs, and group III included 75 patients using basal-bolus insulin regimen with or without OADs. Their mean ages were $55,1 \pm 10,8,55,3 \pm 99$, and $47,7 \pm 10,8$ years, and their mean diabetes durations were $7,6 \pm 4,9,9,9 \pm 5,9$, and 7,2 $\pm 3,6$ years respectively. We observed weight gain among patients receiving any of the insulin regimens, and it was statistically significant in patients on premixed and basal-bolus insulin regimens. In addition, we found increased levels of urea, creatinine, uric acid and UACR in all patients, which were statistically significant in those on basal and premixed insulin regimens. We noticed reductions in systolic and diastolic blood pressures, TC and LDL in all groups. The levels of TG were decreased in patients having premixed and basalbolus insulin regimens and increased in those receiving basal insulin regimen; however, these changes were non-significant. We observed a statistically significant reduction in HbA1c levels after fasting in patients on premixed insulin, whereas patients in other groups showed a nonsignificant increase. The different changes in anthropometric and biochemical variables between Pre (visit A) and Post (visit B) Ramadan fasting among the three studied groups are shown in Table 1. 
Table (1): Comparison between before (visit A) and after (visit B) Ramadan fasting regarding changes in different anthropometric and biochemical variables among the three studied groups.

\begin{tabular}{|c|c|c|c|c|c|c|c|c|c|c|}
\hline \multirow{2}{*}{\multicolumn{2}{|c|}{ Variable }} & \multicolumn{3}{|c|}{ Group I } & \multicolumn{3}{|c|}{ Group II } & \multicolumn{3}{|c|}{ Group III } \\
\hline & & $\begin{array}{c}\text { Visit } \\
\text { A }\end{array}$ & $\begin{array}{c}\text { Visit } \\
\text { B }\end{array}$ & $\mathrm{P}$ value & $\begin{array}{c}\text { Visit } \\
\text { A }\end{array}$ & $\begin{array}{c}\text { Visit } \\
\text { B }\end{array}$ & $\mathrm{P}$ value & $\begin{array}{c}\text { Visit } \\
\text { A }\end{array}$ & $\begin{array}{c}\text { Visit } \\
\text { B }\end{array}$ & $P$ value \\
\hline \multicolumn{2}{|c|}{$\begin{array}{c}\text { Weight } \\
\text { (Kilograms) }\end{array}$} & $\begin{array}{c}88.89 \\
\pm \\
13.06 \\
\end{array}$ & $\begin{array}{c}90.22 \\
\pm \\
17.16 \\
\end{array}$ & 0.249 & $\begin{array}{c}85.12 \\
\pm \\
16.22 \\
\end{array}$ & $\begin{array}{c}86.12 \\
\pm \\
16.04 \\
\end{array}$ & $0.015 *$ & $\begin{array}{c}86.78 \\
\pm \\
14.39 \\
\end{array}$ & $\begin{array}{c}87.55 \\
\pm \\
14.81\end{array}$ & 0.011* \\
\hline \multicolumn{2}{|r|}{ BMI } & $\begin{array}{r}33.34 \\
\pm 5.29\end{array}$ & $\begin{array}{r}33.11 \\
\pm 8.53\end{array}$ & 0.828 & $\begin{array}{r}32.02 \\
\pm 6.34\end{array}$ & $\begin{array}{r}32.22 \\
\pm 6.79\end{array}$ & 0.772 & $\begin{array}{r}33.15 \\
\pm 5.79\end{array}$ & $\begin{array}{r}33.36 \\
\pm 5.93\end{array}$ & 0.795 \\
\hline \multicolumn{2}{|c|}{$\begin{array}{c}\text { Waist } \\
\text { circumference } \\
(\mathrm{Cm}) \\
\end{array}$} & $\begin{array}{c}100.4 \\
1 \pm \\
11.71 \\
\end{array}$ & $\begin{array}{c}100.2 \\
3 \pm \\
11.57 \\
\end{array}$ & 0.546 & $\begin{array}{c}98.66 \\
\pm \\
14.79 \\
\end{array}$ & $\begin{array}{c}98.57 \\
\pm \\
15.46 \\
\end{array}$ & 0.881 & $\begin{array}{c}96.39 \\
\pm \\
13.73 \\
\end{array}$ & $\begin{array}{c}97.92 \\
\pm \\
17.14 \\
\end{array}$ & 0.316 \\
\hline \multicolumn{2}{|c|}{$\mathrm{SBP}(\mathrm{mmHg})$} & $\begin{array}{c}132.3 \\
0 \pm \\
17.15\end{array}$ & $\begin{array}{c}129.7 \\
7 \pm \\
13.18\end{array}$ & 0.011* & $\begin{array}{c}132.2 \\
6 \pm \\
15.05\end{array}$ & $\begin{array}{c}130.6 \\
3 \pm \\
11.14\end{array}$ & $0.021 *$ & $\begin{array}{c}129.8 \\
7 \pm \\
15.42\end{array}$ & $\begin{array}{c}128.8 \\
7 \pm \\
12.88\end{array}$ & 0.202 \\
\hline \multicolumn{2}{|c|}{$\mathrm{DBP}(\mathrm{mmHg})$} & $\begin{array}{l}80.80 \\
\pm 9.11\end{array}$ & $\begin{array}{l}80.34 \\
\pm 8.24\end{array}$ & 0.528 & $\begin{array}{l}81.43 \\
\pm 9.00\end{array}$ & $\begin{array}{r}81.20 \\
\pm 7.84\end{array}$ & 0.628 & $\begin{array}{l}80.00 \\
\pm 8.54\end{array}$ & $\begin{array}{r}79.73 \\
\pm 6.62\end{array}$ & 0.654 \\
\hline \multirow{2}{*}{ 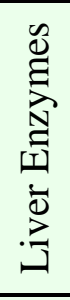 } & $\begin{array}{c}\text { ALT } \\
(\mathrm{IU} / \mathrm{L})\end{array}$ & $\begin{array}{c}32.61 \\
\pm \\
16.24 \\
\end{array}$ & $\begin{array}{c}31.75 \\
\pm \\
14.89 \\
\end{array}$ & 0.385 & $\begin{array}{c}35.25 \\
\pm \\
20.72 \\
\end{array}$ & $\begin{array}{c}37.01 \\
\pm \\
18.38 \\
\end{array}$ & $0.005 *$ & $\begin{array}{c}29.36 \\
\pm \\
13.84 \\
\end{array}$ & $\begin{array}{c}29.52 \\
\pm \\
13.78 \\
\end{array}$ & 0.865 \\
\hline & $\begin{array}{c}\text { AST } \\
(\mathrm{IU} / \mathrm{L})\end{array}$ & $\begin{array}{c}29.11 \\
\pm \\
18.14 \\
\end{array}$ & $\begin{array}{c}26.06 \\
\pm \\
13.95 \\
\end{array}$ & $0.041 *$ & $\begin{array}{c}28.94 \\
\pm \\
15.86 \\
\end{array}$ & $\begin{array}{c}30.28 \\
\pm \\
13.84 \\
\end{array}$ & $0.007 *$ & $\begin{array}{c}26.77 \\
\pm \\
19.23 \\
\end{array}$ & $\begin{array}{c}26.09 \\
\pm \\
19.21 \\
\end{array}$ & 0.347 \\
\hline \multirow{3}{*}{ 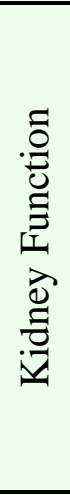 } & $\begin{array}{c}\text { Urea } \\
\text { (mg/dL) }\end{array}$ & $\begin{array}{l}31.34 \\
\pm 8.55\end{array}$ & $\begin{array}{l}33.71 \\
\pm 8.75\end{array}$ & 0.001* & $\begin{array}{c}33.36 \\
\pm \\
11.51 \\
\end{array}$ & $\begin{array}{c}35.57 \\
\pm \\
12.58 \\
\end{array}$ & $\begin{array}{c}<0.0001 \\
*\end{array}$ & $\begin{array}{l}29.17 \\
\pm 7.16\end{array}$ & $\begin{array}{r}30.79 \\
\pm 8.29\end{array}$ & 0.086 \\
\hline & $\begin{array}{c}\text { Creatinin } \\
\mathrm{e} \\
(\mathrm{mg} / \mathrm{dL}) \\
\end{array}$ & $\begin{array}{c}0.94 \pm \\
0.33\end{array}$ & $\begin{array}{c}1.01 \pm \\
0.21\end{array}$ & $0.002 *$ & $\begin{array}{c}0.99 \pm \\
0.54\end{array}$ & $\begin{array}{c}1.09 \pm \\
0.50\end{array}$ & 0.011* & $\begin{array}{c}0.89 \pm \\
0.29\end{array}$ & $\begin{array}{c}0.97 \pm \\
0.30\end{array}$ & 0.253 \\
\hline & $\begin{array}{l}\text { UACR } \\
(\mathrm{mg} / \mathrm{g})\end{array}$ & $\begin{array}{c}74.59 \\
\pm \\
128.2 \\
4\end{array}$ & $\begin{array}{c}90.58 \\
\pm \\
189.1 \\
0\end{array}$ & $\begin{array}{c}<0.0001 \\
*\end{array}$ & $\begin{array}{c}78.33 \\
\pm \\
137.1 \\
5\end{array}$ & $\begin{array}{c}90.77 \\
\pm \\
155.5 \\
1\end{array}$ & $\begin{array}{c}<0.0001 \\
*\end{array}$ & $\begin{array}{c}59.66 \\
\pm \\
74.14\end{array}$ & $\begin{array}{c}68.39 \\
\pm \\
88.59\end{array}$ & $0.005 *$ \\
\hline \multicolumn{2}{|c|}{$\begin{array}{l}\text { Uric Acid } \\
(\mathrm{mg} / \mathrm{dL})\end{array}$} & $\begin{array}{r}4.54 \pm \\
0.81\end{array}$ & $\begin{array}{c}5.09 \pm \\
0.91\end{array}$ & $\begin{array}{c}<0.0001 \\
*\end{array}$ & $\begin{array}{r}4.69 \pm \\
0.94\end{array}$ & $\begin{array}{c}5.11 \pm \\
1.09\end{array}$ & $\begin{array}{c}<0.0001 \\
*\end{array}$ & $\begin{array}{r}4.46 \pm \\
0.80\end{array}$ & $\begin{array}{c}4.74 \pm \\
1.16\end{array}$ & $0.026 *$ \\
\hline \multirow{2}{*}{ 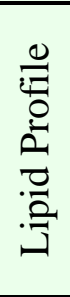 } & $\begin{array}{c}\mathrm{TC} \\
(\mathrm{mg} / \mathrm{dL})\end{array}$ & $\begin{array}{c}189.2 \\
6 \pm \\
37.32 \\
\end{array}$ & $\begin{array}{c}175.6 \\
4 \pm \\
29.59 \\
\end{array}$ & $\begin{array}{c}<0.0001 \\
*\end{array}$ & $\begin{array}{c}184.0 \\
4 \pm \\
38.75 \\
\end{array}$ & $\begin{array}{c}178.7 \\
7 \pm \\
36.88 \\
\end{array}$ & $0.037 *$ & $\begin{array}{c}189.6 \\
2 \pm \\
44.87 \\
\end{array}$ & $\begin{array}{c}177.5 \\
5 \pm \\
37.01 \\
\end{array}$ & $\begin{array}{c}<0.0001 \\
*\end{array}$ \\
\hline & $\begin{array}{c}\text { LDL } \\
(\mathrm{mg} / \mathrm{dL})\end{array}$ & $\begin{array}{c}110.3 \\
0 \pm \\
34.69\end{array}$ & $\begin{array}{c}102.4 \\
9 \pm \\
33.71\end{array}$ & $0.002 *$ & $\begin{array}{c}112.1 \\
8 \pm \\
36.57\end{array}$ & $\begin{array}{c}110.9 \\
3 \pm \\
37.00\end{array}$ & 0.103 & $\begin{array}{c}107.7 \\
9 \pm \\
37.03\end{array}$ & $\begin{array}{c}101.5 \\
2 \pm \\
33.09\end{array}$ & 0.099 \\
\hline
\end{tabular}




\begin{tabular}{|c|c|c|c|c|c|c|c|c|c|}
\hline $\begin{array}{c}\mathrm{HDL} \\
(\mathrm{mg} / \mathrm{dL})\end{array}$ & $\begin{array}{r}44.16 \\
\pm 8.52 \\
\end{array}$ & $\begin{array}{l}43.96 \\
\pm 5.66\end{array}$ & 0.872 & $\begin{array}{r}43.21 \\
\pm 6.58 \\
\end{array}$ & $\begin{array}{r}44.86 \\
\pm 4.81\end{array}$ & $0.001 *$ & $\begin{array}{l}43.57 \\
\pm 6.26\end{array}$ & $\begin{array}{l}43.94 \\
\pm 4.54\end{array}$ & 0.541 \\
\hline $\begin{array}{c}\mathrm{TG} \\
(\mathrm{mg} / \mathrm{dL})\end{array}$ & $\begin{array}{c}182.8 \\
1 \pm \\
82.19\end{array}$ & $\begin{array}{c}186.0 \\
2 \pm \\
52.22\end{array}$ & 0.886 & $\begin{array}{c}169.8 \\
5 \pm \\
68.21\end{array}$ & $\begin{array}{c}166.6 \\
5 \pm \\
55.06\end{array}$ & 0.515 & $\begin{array}{c}184.7 \\
6 \pm \\
103.9 \\
2\end{array}$ & $\begin{array}{c}176.0 \\
0 \pm \\
83.44\end{array}$ & 0.141 \\
\hline HbAlc (\%) & $\begin{array}{c}8.71 \pm \\
1.45\end{array}$ & $\begin{array}{c}8.77 \pm \\
1.15\end{array}$ & 0.693 & $\begin{array}{c}8.79 \pm \\
1.72\end{array}$ & $\begin{array}{c}8.31 \pm \\
1.30\end{array}$ & $\begin{array}{c}<0.0001 \\
*\end{array}$ & $\begin{array}{c}8.68 \pm \\
1.63\end{array}$ & $\begin{array}{c}8.69 \pm \\
1.31\end{array}$ & 0.897 \\
\hline
\end{tabular}

Hypoglycemic events whether documented or symptomatic (44\% and 52\% respectively) were more prevalent among patients on basal-bolus insulin regimen. The number of episodes of

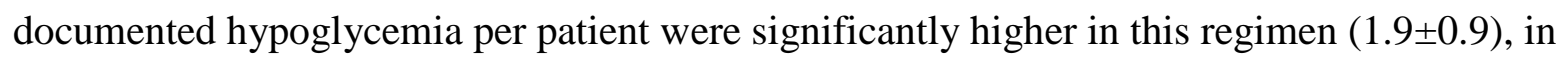
addition to non-fasting days due to hypoglycemia compared to the other two regimens. We found no significant difference in the number of patients with broken fast days caused by dysregulation of blood glucose levels. however, we found a statistically significant increase due to conditions unrelated to diabetes control in group III patients as compared to the other two groups. We reported non-significant difference among the studied groups regarding neither the number of completed fasting days nor the prevalence of hyperglycemic attacks confirmed by SMBG measurements $\geq 300 \mathrm{mg} / \mathrm{dl}$; nevertheless, hyperglycemic events depending only on the occurrence of symptoms were prevalent in patients receiving pre-mixed insulin regimen (Table 2).

Table (2): Comparison between dysglycemic events and non-fasting days among the different study groups during the fasting month of Ramadan.

\begin{tabular}{|l|l|l|l|l|l|l|}
\hline \multicolumn{2}{|l|}{ Variable } & $\begin{array}{l}\text { Group I } \\
\text { (N=87) }\end{array}$ & $\begin{array}{l}\text { Group } \\
\text { II } \\
(\mathrm{N}=175)\end{array}$ & $\begin{array}{l}\text { Group III } \\
\text { (N=75) }\end{array}$ & P-value \\
\hline $\begin{array}{l}\text { The prevalence } \\
\text { of } \\
\text { hypoglycemic } \\
\text { events N \% }\end{array}$ & $\begin{array}{l}\text { Documented } \\
\text { hypoglycemia }\end{array}$ & Yes & $21(24.1)$ & $\begin{array}{l}68 \\
(38.9)\end{array}$ & $33(44.0)$ & $0.018^{*}$ \\
\cline { 2 - 7 } & No & $66(75.9)$ & $\begin{array}{l}107 \\
(61.1)\end{array}$ & $42(56.0)$ & \\
\cline { 2 - 7 } & $\begin{array}{l}\text { Symptomatic } \\
\text { hypoglycemia }\end{array}$ & Yes & $25(28.7)$ & $\begin{array}{l}77 \\
(44.0)\end{array}$ & $39(52.0)$ & $0.008^{*}$ \\
\cline { 2 - 6 } & No & $62(71.3)$ & $\begin{array}{l}98 \\
(56.0)\end{array}$ & $38(48.0)$ & \\
\hline $\begin{array}{l}\text { The number of } \\
\text { hypoglycemic } \\
\text { attacks per } \\
\text { patient mean } \pm \\
\text { SD }\end{array}$ & $\begin{array}{l}\text { Documented } \\
\text { Hypoglycemia }\end{array}$ & & $1.3 \pm 0.7$ & $\begin{array}{l}1.6 \pm \\
0.9\end{array}$ & $1.9 \pm 0.9$ & $0.046^{*}$ \\
\cline { 2 - 6 } & $\begin{array}{l}\text { Symptomatic } \\
\text { hypoglycemia }\end{array}$ & & $1.8 \pm 0.7$ & $\begin{array}{l}1.7 \pm \\
0.9\end{array}$ & $2.0 \pm 1.0$ & 0.329 \\
\hline
\end{tabular}




\begin{tabular}{|c|c|c|c|c|c|c|}
\hline \multirow{4}{*}{$\begin{array}{c}\text { The incidence } \\
\text { of } \\
\text { hyperglycemia } \\
\mathrm{N} \%\end{array}$} & $\begin{array}{l}\text { Documented } \\
\text { Hyperglycemia }\end{array}$ & Yes & $21(24.1)$ & $\begin{array}{l}49 \\
(28.0)\end{array}$ & $22(29.3)$ & \multirow[t]{2}{*}{0.727} \\
\hline & & No & $66(75.9)$ & $\begin{array}{l}126 \\
(72.0)\end{array}$ & $53(70.7)$ & \\
\hline & $\begin{array}{l}\text { Symptomatic } \\
\text { hyperglycemia }\end{array}$ & Yes & $3(3.4)$ & $\begin{array}{l}31 \\
(17.7)\end{array}$ & $12(16.0)$ & \multirow[t]{2}{*}{$0.005^{*}$} \\
\hline & & No & $84(96.6)$ & $\begin{array}{l}144 \\
(82.3)\end{array}$ & $63(84.0)$ & \\
\hline $\begin{array}{l}\text { The mean } \\
\text { number of } \\
\text { successfully } \\
\text { fasted days } \\
\text { mean } \pm \text { SD }\end{array}$ & $\begin{array}{l}\text { Total } \\
\text { successfully } \\
\text { fasted days }\end{array}$ & & $27.49 \pm 1.42$ & & $27.89 \pm 1.23$ & $27.35 \pm 1.44$ \\
\hline \multirow{2}{*}{$\begin{array}{l}\text { The prevalence } \\
\text { of non-fasting } \\
\text { patients } \mathrm{N} \%\end{array}$} & $\begin{array}{l}\text { Due to } \\
\text { Diabetes }\end{array}$ & & $29(33.3)$ & $\begin{array}{l}78 \\
(44.6)\end{array}$ & $30(40.0)$ & 0.217 \\
\hline & $\begin{array}{l}\text { Due to other } \\
\text { causes }\end{array}$ & & $2(2.3)$ & $0(0.0)$ & $12(16.0)$ & $<0.0001^{*}$ \\
\hline $\begin{array}{l}\text { The mean } \\
\text { number of non- } \\
\text { fasting days } \\
\text { (per patient) } \\
\text { caused by } \\
\text { hypoglycemia } \\
\text { mean } \pm \text { SD }\end{array}$ & & & $1.4 \pm 1.4$ & $\begin{array}{l}2.1 \pm \\
1.7\end{array}$ & $2.6 \pm 2.2$ & $0.007^{*}$ \\
\hline
\end{tabular}

None of our patients reported the need for hospitalization or emergency room visit during Ramadan.

\section{Discussion:}

This study compared the safety and efficacy of three different insulin regimens in type 2 diabetic patients who insisted on fasting during Ramadan 1437 (Hijra) at Fayoum Governorate. Our results showed that the mean number of successfully fasted days were $27.49 \pm 1.42$, with no significant difference among the studied groups. Also, we found no significant difference among patients regarding the broken fasting days due to dysregulation of blood glucose. These results agree with CREED 2015 study[ $\left.{ }^{7}\right]$, which reported the average number of fasted days to be 27.5 and 27.4 days in high- and low-risk patients respectively. In addition, an approximate day's number (27 days) of 
complete fasting was observed in EPIDIAR study. $\left[{ }^{2}\right]$

The frequency of documented hypoglycemic episodes in groups $\mathrm{A}, \mathrm{B}$, and $\mathrm{C}$ were $24.1 \%$, $38.9 \%$ and $44 \%$, and the mean number of hypoglycemic events per patient were $1.3 \pm 0.7,1.6 \pm 0.9$ and $1.9 \pm 0.9$ respectively; with patients on basal insulin regimen significantly less prone to these events. In this study, the incidence of hypoglycemia during Ramadan was much higher than that documented in CRRED 2017 study $\left[{ }^{8}\right]$ and Hassanein et al. $\left[{ }^{9}\right]$, which were estimated to be $16.8 \%$ and $10.4 \%$ respectively. The high incidence of hypoglycemia observed in our study can be explained by the use of insulin in all of our patients, in addition to the availability of self-monitoring blood glucose measurements, which allowed more documentation of hypoglycemic events. Our results may be supported by the higher frequency of hypoglycemic events detected when flash glucose monitoring data were used in a study done by Bashier et al. $\left[{ }^{4}\right]$, where the mean number of hypoglycemic events per patient were $2.4 \pm 3.1$ in patients receiving basal insulin and 5.0 \pm 5.4 in those receiving premixed and multiple doses of insulin. This highlights the significance of patients' education and blood glucose monitoring for decreasing the frequency of occurrence of hypoglycemia in type 2 diabetic patients who observe Ramadan fasting. We think that there was a minor impact of the use of OAD especially sulfonylurea regarding the risk of hypoglycemia; as the group of patients on the basal bolus regimen had the highest incidence of hypoglycemic episodes although they were not using sulfonylurea at all.

We found non-significant differences regarding the occurrence of symptomatic hyperglycemia $(17.7 \%$ and $16 \%$ in patients taking premixed and basal-bolus regimens respectively). This result is comparable to that reported by Ahmedani et al. $\left[{ }^{10}\right]$; however, in our study none of the patients developed diabetic ketoacidosis or hyperosmolar state, and the differences in the number of patients who broke their fast due to diabetes complications among the studied groups were not significant.

It was remarkable that our patients insisted on fasting despite their high mean $\mathrm{HbAlc}$ values before Ramadan $(8.71 \pm 1.45$, $8.79 \pm 1.72$, and $8.68 \pm 1.63$ in groups $\mathrm{A}, \mathrm{B}$, and $\mathrm{C}$ respectively). Also, the observed weight gain in patients receiving the different insulin regimens, which is a 
common event in Egypt during Ramadan owing to the habitual increase in sweets and sugary juices consumption during this Holly month, especially if it comes in summer.

We found a highly significant rise in UACR in the three studied groups. In addition, there were increments in s. urea and s. creatinine, with variable statistical significances among patients on the three insulin regimens. These findings are comparable to Abushady et al. $\left[{ }^{11}\right]$, who documented an increase in $\mathrm{s}$. urea, s. creatinine, and UACR in T2DM patients with normal renal function tests (with and without albuminuria) after Ramadan fasting. Similarly, Kamar et al. $\left[{ }^{12}\right]$ reported a rise in UACR in diabetic patients after Ramadan fasting. In the current study, these increments irrespective of the insulin regimen used may be explained by the effect of dehydration from prolonged fasting and hot weather; in our study, Ramadan started at June 6 to July 5 , with nearly 16 hours of water deprivation.

In the current study, we documented a drop out of some patients. We excluded those who did not fulfill the 3 measures of blood glucose level in the exact times of the predefined days and some patients did not return in the exact period for reassessment after Ramadan fast. In addition, some patients had the wrong idea that skin pricking is not allowed during fasting, a common false belief adopted by some diabetic Muslims. An earlier study $\left[{ }^{13}\right]$ estimated that $33.6 \%$ of diabetic Muslims believed in this idea. Hence, we carried out patient education sessions at the month before fasting trying to change this belief. Limitations of this study were that we could not accurately assess the dietary history of our patients and the level of their physical activity during Ramadan. Also, many of our patients fasted Ramadan although they were not well-controlled before the month.

In conclusion, the current study reported comparable results regarding safety and efficacy of the three studied insulin regimens used for treatment of type 2 diabetics during Ramadan fasting. No regimen proved to be superior. Patient education before fasting is a mandatory step in management.

\section{References}

1.IDF Diabetes Atlas 2017

2. Salti I, Bénard E, Detournay B, BianchiBiscay M, Le Brigand C, Voinet C, et al. A population-based study of diabetes and its characteristics during the fasting month of Ramadan in 13 countries: results of the 
epidemiology of diabetes and Ramadan 1422/2001 (EPIDIAR) study. Diabetes care. 2004;27:2306-11.

3. Miller CD1, Phillips LS, Ziemer DC, Gallina DL, Cook CB, El-Kebbi IM. Hypoglycemia in patients with type 2 diabetes mellitus. Arch Intern Med. $2001 \mathrm{Jul}$ 9;161(13):1653-9.

4.Bashier AMK, Hussain AKB, Alawadi F, Alsayyah F, Alsaeed M, Rashid F,et al,. Impact of optimum diabetes care on the safety of fasting in Ramadan in adult patients with type 2 diabetes mellitus on insulin therapy. Diabetes Res Clin Pract. 2019 Feb 12. pii: S0168-8227(18)31629-2. doi: 10.1016/j.diabres.2019.01.037.

5. McEwen LN, Ibrahim M, Ali NM, Assaad-Khalil SH, Tantawi HR, Nasr G, et al. Impact of an individualized type 2 diabetes education program on clinical outcomes during Ramadan. BMJ Open Diabetes Res Care. 2015;3:e000111.

6. Diabetes and Ramadan: practical guidelines international diabetes Federation (IDF), in collaboration with the Diabetes and Ramadan (DAR) International Alliance; April 2016.

7. Babineaux S.M., Toaima D., Boye K.S., Zagar A., Tahbaz A., Jabbar A., et al. Multi- country retrospective observational study of the management and outcomes of patients with Type 2 diabetes during Ramadan in 2010 (CREED) Diabet Med, 32 (6) (2015), pp. 819-828, 10.1111/dme.12685. Epub 2015 Apr 10

8. Jabbar A, Hassanein M, Beshyah SA, Boye KS, Yu M, Babineaux SM. CREED study: hypoglycemia during Ramadan in individuals with type 2 diabetes mellitus from three continents. Diabetes Res Clin Pract Elsevier. 2017;132:19-26.

9. Mohamed Hassanein, Fatheya F. Al Awadia, Khaled El Sayed El Hadidy,Ali SS, Echtay A, Djaballah K, et al. The characteristics and pattern of care for the type 2 diabetes mellitus population in the MENA region during Ramadan: An international prospective study (DARMENA T2DM). Diabetes Res Clin Pract. 2019 Feb 27. pii: S0168-8227(18)31661-9. doi: 10.1016/j.diabres.2019.02.020

10. Ahmedani MY, Alvi SF, Haque MS, Fawwad A, Basit A. Implementation of Ramadan-specific diabetes management recommendations: a multi-centered prospective study from Pakistan. J Diabetes Metab Disord 2014;13:37. 
11. Abushady MM, Samy M, Bekhet M, Abdullah A. Effect of Ramadan fasting on renal function in patients with type 2 diabetes. Diabetes Res Clin Pract. 2019 Jun 10. pii: S0168-8227(19)30271-2. doi:

10.1016/j.diabres.2019.05.036.

12. Kamar E.G. Mohamed, Orabi A. Abbas, Salem M. Ihab And El- Shabrawy M. Arafa. Effect of Ramadan Fasting on Diabetic Micro-vascular Complication.

Z.U.M.J.Vol.20; N.2; March; 2014.

13.Masood SN, Sheikh MA, Masood Y, Hakeem R, Shera AS. Beliefs of people with diabetes about skin prick during Ramadan fasting. Diabetes Care. 2014 Apr;37(4):e689. doi: $10.2337 / \mathrm{dc} 13-2277$. 